\title{
Effect of disturbances on the genetic diversity of an old-forest associated lichen
}

Post-print/Accepted manuscript

Silke Werth

Helene H. Wagner

Rolf Holderegger

Jesse M. Kalwij

Christoph Scheidegger

WERTH, S., WAGNER, H. H., HOLDEREGGER, R., KALWIJ, J. M. and SCHEIDEGGER, C. (2006), Effect of disturbances on the genetic diversity of an old-forest associated lichen. Molecular Ecology, 15: 911-921. doi:10.1111/j.1365-294X.2006.02838.x

This is the peer reviewed version of the following article: WERTH, S., WAGNER, H. H., HOLDEREGGER, R., KALWIJ, J. M. and SCHEIDEGGER, C. (2006), Effect of disturbances on the genetic diversity of an old-forest associated lichen. Molecular Ecology, 15: 911-921, which has been published in final form at doi:10.1111/j.1365-294X.2006.02838.x This article may be used for noncommercial purposes in accordance with Wiley Terms and Conditions for Self-Archiving.

\section{HOW TO CITE TSPACE ITEMS}

Always cite the published version, so the author(s) will receive recognition through services that track citation counts, e.g. Scopus. If you need to cite the page number of the TSpace version (original manuscript or accepted manuscript) because you cannot access the published version, then cite the TSpace version in addition to the published version using the permanent URI (handle) found on the record page. 
1. Title: Effect of disturbances on the genetic diversity of an old-forest associated lichen

2. Authors: Silke Werth, Helene H. Wagner, Rolf Holderegger, Jesse M. Kalwij, Christoph Scheidegger

3. Author affiliation:

Division of Ecological Genetics, WSL Swiss Federal Research Institute, Zürcherstrasse 111, CH-8903 Birmensdorf, Switzerland

4. Keywords: Lichenised ascomycetes, population history, landscape genetics, spatial autocorrelation, microsatellites, Lobaria pulmonaria

5. Corresponding author: Silke Werth, Division of Ecological Genetics, WSL Swiss Federal Research Institute, Zürcherstrasse 111, CH-8903 Birmensdorf, Switzerland, Fax 0041-44739-2215, Email: silke.werth@wsl.ch

6. Running head: Genetic diversity is affected by disturbances

7. Word count: 7238 


\begin{abstract}
Lichens associated with old forest are commonly assumed to be negatively affected by tree logging or natural disturbances. However, in this study performed in a spruce-dominated sylvopastoral landscape in the Swiss Jura Mountains, we found that genetic diversity of the epiphytic old-forest lichen Lobaria pulmonaria depends on the type of disturbance. We collected 923 thalli from 41 sampling plots of 1 ha corresponding to the categories stand-replacing disturbance (burnt), intensive logging (logged) and uneven-aged forestry (uneven-aged), and analysed the thalli at six mycobiontspecific microsatellite loci. We found evidence for multiple independent colonisations of demes located in burnt and logged areas. Using spatial autocorrelation methods, the spatial scale of the genetic structure caused by the clonal and recombinant component of genetic variation was determined. Spatial autocorrelation of genotype diversity was strong at short distances up to $50 \mathrm{~m}$ in logged demes, up to $100 \mathrm{~m}$ in uneven-aged demes, with the strongest autocorrelation up to $150 \mathrm{~m}$ for burnt demes. The spatial autocorrelation was predominantly attributed to clonal dispersal of vegetative propagules. After accounting for the clonal component, we did not find significant spatial autocorrelation in gene diversity. This pattern may indicate low dispersal ranges of clonal propagules, but random dispersal of sexual ascospores. Genetic diversity was highest in logged demes, and lowest in burnt demes. Our results suggest that genetic diversity of epiphytic lichen demes may not necessarily be impacted by stand-level disturbances for extended time periods.
\end{abstract}




\section{Introduction}

Genetic diversity of natural populations, an important component of biodiversity, may be affected by disturbance (Bradshaw 2004; Baucom et al. 2005; Volis et al. 2005). In forested ecosystems, wind-throws and fires belong to the natural disturbance regime. In many parts of Central Europe, human influence has added various types of forest disturbances (Bradshaw 2004). For instance, the traditional sylvopastoral landscapes found in many mountainous areas of Europe are regularly disturbed by cattle grazing or timber logging (Kirby et al. 1995; Gillet et al. 2002). At the same time, however, these systems often have a high species richness (Vittoz 1998) and may harbour e.g. populations of endangered old-forest species such as the epiphytic lichen Lobaria pulmonaria (Zoller et al. 1999).

If a disturbance event leads to a significant reduction in the habitat of a particular population, the local population size generally declines. This may lead to a population bottleneck, involving an instant loss of rare alleles (Hartl \& Clark 1997). If population size remains small over an extended time period, rare alleles may further be lost due to genetic drift, leading to a continuing decrease of genetic diversity over time (Nei et al. 1975), particularly in terms of allelic richness (Widmer \& Lexer 2001). Subsequently, other population genetic consequences of small population sizes may occur, as the population enters an extinction vortex (Tanaka 2000; Frankham et al. 2002). In self-incompatible organisms such as some plants or fungi, the likelihood that compatible mating types are present is low in very small populations, and their absence may prevent sexual reproduction (Vekemans et al. 1998; Zoller et al. 1999; Taylor et al. 2000; Walser et al. 2004). On the other hand, if disturbance has caused the local extinction of a species, the habitat is open for recolonisation during forest succession. In many cases, the habitat is recolonised by only a few founders, leading to low genetic diversity in the new population (founder event; Hartl \& Clark 1997). However, as new individuals (or gametes in plants and fungi) enter the population over time, genetic diversity increases and the footprints of severe bottlenecks or of founder events are successively erased.

In several insect-pollinated woody plant species, gene flow was not reduced under silvicultural management (Nason \& Hamrick 1997; Sork et al. 2005), and in a wind-pollinated tree species, habitat fragmentation even led to facilitated pollen movement and thus increase gene flow, explaining why high genetic diversity was found in remnant populations (Bacles et al. 2005). However, when comparing continuous and naturally fragmented populations in a tropical tree species, fragmented populations exhibited slightly lower genetic diversity (Pither et al. 2003). Studies of vascular epiphytes have shown lower genetic diversity of disturbed, spatially isolated populations following forest fragmentation (Gonzalez-Astorga et al. 2004; Trapnell \& Hamrick 2005). An interesting question is if cryptogamic epiphytes, e.g. bryophytes, lichens, and fungi, also exhibit lower genetic diversity in disturbed populations, even though they mostly have smaller, probably more easily wind-dispersed diaspores than some vascular epiphytes (Bailey 1976).

Lichens have a long generation time, which is one reason why they are considered sensitive to disturbances such as logging (Gilbert 1977; Seaward 1982). Consequently, random sampling effects such as bottlenecks or founder events in the population history should be imprinted in the genetic diversity of lichens for a comparatively long period. Recent studies in population genetics of lichens have mainly focused on large spatial scales, comparing populations among regions and continents 
(Högberg et al. 2002; Myllys et al. 2003; Printzen \& Ekman 2003; Printzen et al. 2003; Walser et al. 2005). Very little is known about genetic diversity, gene flow, and population dynamics of lichens within landscapes, and about the effect of disturbances on epiphytic lichen populations. To overcome this gap in knowledge, we performed a population genetic study at the landscape scale focussing on the comparison of demes of an epiphytic lichen within a sylvopastoral landscape where stand-replacing disturbances had been reconstructed (Kalwij et al. in press). Our model organism, the epiphytic lichen L. pulmonaria, is described as an indicator lichen of forest canopy continuity in Europe (Rose 1992). The species is also thought to be dispersal-limited (Scheidegger et al. 1995; Walser et al. 2001). Since the haploid fungus of L. pulmonaria produces both vegetative and sexual propagules (Yoshimura 1971), its genetic structure consists of a clonal as well as a recombinant component. Both propagule types, vegetative soredia containing both the haploid fungus and the green algal component and sexual fungal ascospores, are wind dispersed (Werth, S. unpublished data; Walser et al. 2001). L. pulmonaria has a generation time of the clonal component of 35 years or longer in central Europe (Scheidegger \& Goward 2002). Owing to forest management with short rotation cycles and to air pollution, $L$. pulmonaria has suffered a severe decline in Central Europe during the last decades. The species is considered vulnerable in the Red List of Switzerland (Scheidegger et al. 2002) and is endangered (Hallingbäck \& Martinsson 1987; Wirth 1995; Wirth et al. 1996; Türk \& Hafellner 1999; Søchting \& Alstrup 2002) or extinct (Aptroot et al. 1999) in other European countries.

In our study area, a sylvopastoral landscape dominated by spruce forests (Picea abies L.) and wooded pastures in the Swiss Jura Mountains with a spatial extent of $46^{\circ} 30^{\prime}-34^{\prime} \mathrm{N}$ and $06^{\circ} 10^{\prime}-16^{\prime} \mathrm{E}$ at an elevation of 1300-1450 m, L. pulmonaria exhibits large population sizes. The local carrier trees of $L$. pulmonaria, sycamore maple (Acer pseudoplatanus L.), and beech (Fagus sylvatica L.), are scarce and irregularly distributed within the mixed forest patches (Kalwij et al. in press).

Forests in the entire study area are subject to tree-level forest management, i.e., unevenaged forestry, where individual trees of all size classes are harvested in order to maintain a constant size class distribution (category: uneven-aged). Two forest areas in the north and west of the study area (Fig. 1) were additionally affected by $19^{\text {th }}$ century disturbances (categories: burnt and logged; Kalwij et al. in press). Large population sizes of L. pulmonaria were found in all three disturbance categories (Kalwij et al. in press). This raises the questions of how the recolonisation process of such differentially disturbed habitats by L. pulmonaria took place, and how it affected local genetic diversity.

Specifically, this paper addresses the following questions: (1) Were demes of L. pulmonaria, defined as assemblages of thalli within 1-ha sampling plots, affected by a stand-replacing disturbance founded by only a few independent immigration events? (2) What is the effect of stand-level disturbances on genetic diversity in L. pulmonaria demes and on genetic distance among demes, and does it depend on deme size in terms of the number of colonised trees? (3) Is there spatial genetic structure, and if so, does this structure differ between the three disturbance types? (4) Does the spatial genetic structure differ between clonal and recombinant components, and, hence, what are the dispersal ranges of clonal vs. recombinant propagules? We discuss the results in the context of conservation strategies for L. pulmonaria.

\section{Methods}


Sampling design

We investigated 41 1-ha plots, where the occurrence of L. pulmonaria and its carrier trees, maple and beech was known from Kalwij et al. (in press). Kalwij et al. (in press) delineated two standlevel disturbances: (i) Intensive, stand-level logging between 1850 and 1900, possibly selective for $P$. abies, for charcoal production (in the following referred to as logged; Fig. 1) and (ii) large-scale, standreplacing logging in 1870, followed by wind throw and, in the next year, a two-week fire (in the following named burnt; Fig. 1). Within the burnt area, single old trees were present which survived the stand-replacing disturbance (J. Bolli, unpublished data). We refer to plots under uneven-aged forestry as uneven-aged. From the logged area, nine plots were chosen and from the burnt area, 12 plots were investigated. Twenty plots were classified as uneven-aged (Fig. 1).

A hierarchical random sample of 923 thalli was collected from the 41 plots. Within each plot, all carrier trees of L. pulmonaria found by Kalwij et al. (in press) were searched for L. pulmonaria. A maximum of 24 thalli per deme were randomly selected from different trees. If there were fewer than 24 trees colonised by L. pulmonaria, multiple thalli were sampled from the same tree (for statistical treatment of unbalanced sampling see below). If there were fewer than 24 thalli in a plot, every thallus found was included. From each thallus, we collected a single lobe tip of a minimum area of $3 \mathrm{~cm}^{2}$.

\section{Molecular analysis}

Sample preparation for DNA extractions followed Walser et al. (2003). Total DNA was isolated using the DNeasy 96 plant kit (Qiagen, Hilden, Germany) according to the manufacturer's protocol.

Six unlinked (Walser et al. 2004) fungal microsatellite loci (Walser et al. 2003) were analysed. A modified set of PCR primers (table 3 in Walser et al. 2004) was used in two multiplex PCR reactions of $10 \mu \mathrm{L}$ each. The first multiplex PCR contained $1 \mu \mathrm{L}$ genomic DNA, $25 \mathrm{nM}$ of the primers for $L P u 03$ and $L P u 09,125 \mathrm{nM}$ of the primers for $L P u 15,1 \times$ PCR buffer (Sigma, Saint Louis, MO, USA), $1.87 \mathrm{mM} \mathrm{MgCl}_{2}, 50 \mu \mathrm{M}$ of dNTPs (Promega, Madison, WI, USA), and 0.75 U DNA polymerase (Sigma, Saint Louis, MO, USA). The second multiplex differed in that primer concentration was $125 \mathrm{nM}$ for all of the six primers used (loci LPu16, LPu20, LPu27). We used the fluorescent labelling of primers proposed by Walser et al (2004). The amplification protocol of both multiplex amplification reactions began with an initial denaturation at $94^{\circ} \mathrm{C}$ for $120 \mathrm{~s}, 29$ cycles of denaturation at $94^{\circ} \mathrm{C}$ for $60 \mathrm{~s}$, annealing at $57^{\circ} \mathrm{C}$ for $60 \mathrm{~s}$ and extension at $72^{\circ} \mathrm{C}$ for $60 \mathrm{~s}$, followed by a final extension at $72^{\circ} \mathrm{C}$ for 45 minutes. All amplification reactions were performed with a PTC-100 thermal cycler (MJ Research, Waltham, USA). Fragment sizes of PCR products were determined on an ABI3100-avant automatic sequencer (Applied Biosystems, Foster City, CA, USA). Alleles were sized with an internal size standard (ROX 500, Applied Biosystems, Foster City, CA, USA). A reference sample of L. pulmonaria with known allele sizes was run on each plate to check repeatability of the allele sizing. Genotyping was done using GENOTYPER 2.1 (Applied Biosystems, Foster City, CA, USA).

\section{Data analysis}


There were missing values for 13 thalli, and in 15 thalli, multiple alleles were found for at least one locus. These latter 15 samples most likely consisted of more than one genetic individual of the haploid mycobiont. Alternatively, by chance, fertile dikaryotic and diploid hyphae within thalli might have been used for extraction. We thus excluded 28 thalli from statistical analyses (895 thalli remaining).

On every tree from which we collected L. pulmonaria, we estimated the total thallus area of $L$. pulmonaria in $\mathrm{cm}^{2}$. If the cumulative thallus area was larger than $1 \mathrm{dm}^{2}$, we estimated it as the number of DINA4-size sheets covered by L. pulmonaria on the tree. Furthermore, we roughly estimated the number of thalli on each tree from which we collected L. pulmonaria, counting up to 24 thalli or, for larger numbers, using the following thallus number classes: 25-50, 51-75, 76-100, 101-150, 151-200, 200-300, 300-400. We calculated the sum of the number of thalli or of the median class value over all trees on which we had sampled L. pulmonaria per plot (deme census size), as well as the sum of the thallus area per plot (deme thallus area). Note that by this procedure, thallus number and thallus area were underestimated in plots where more than 24 trees were present, which was the case in three uneven-aged plots with 34, 30 and 26 trees colonised and in one logged plot with 104 trees colonised by L. pulmonaria.

Our sampling design was unbalanced for the number of thalli sampled per tree, which differed among plots. To overcome this problem, we based our analyses on averaged values from 1000 reduced data sets, created by randomly selecting one thallus per tree.

We estimated the minimum number of immigration (including original colonisation) events (C) per deme as the number of alleles at the most variable locus (Walser et al. 2003). To test for a deviation of $C$ per disturbance category from uniformity, we computed a $\chi^{2}$-test in $\mathrm{R}$ (Anonymous 2004).

To quantify genetic diversity of demes for a comparison of different disturbance categories, we calculated Nei's unbiased gene diversity $\left(H\right.$; Nei 1978) for each deme as $H=\frac{1}{r}\left(\sum_{k=1}^{r} h_{k}\right)$, where $h_{k}=\frac{n}{n-1}\left(1-\sum_{i=1}^{m_{k}} x_{i k}{ }^{2}\right), x_{i k}$ is the frequency of the $i$ th allele at the $k$ th locus in a subpopulation, $m_{k}$ is the number of alleles at the $k$ th locus, and $r$ the number of loci analysed. Furthermore, we calculated the number of multilocus genotypes $(G)$ and the percentage of multilocus genotypes per deme $(M)$, i.e. the number of multilocus genotypes divided by the number of thalli. For the calculation of $H, G$ and $M$, we wrote our own code in the R statistical package for haploid data (Anonymous 2004). We performed analysis of covariance (ANCOVA) of $G, H$ and $M$ as a function of the log-transformed number of $L$. pulmonaria carrier trees per deme as covariate and disturbance category as factor (three levels). Histograms of the residuals were inspected visually in order to check if they were close to normal distribution, and otherwise, a transformation of the response variable was performed to ensure approximately normally distributed residuals. To test for homogeneity of variance among disturbance categories, Levene's test was preformed in R (library Rcmdr, xxx). 
To assess if there were major differences in genetic distance among disturbance categories, we calculated Nei's minimum genetic distance between demes $\left(D_{m}\right.$; Takezaki \& Nei 1996) as $D_{m}=\left(J_{a}+\right.$ $\left.J_{b}\right) / 2-J_{a b}$, where $J_{a}$ and $J_{b}$ are the average identity over loci within subpopulation $a$ and $b$, respectively, calculated as $J_{a}=\frac{1}{r} \sum_{j}^{r} \sum_{i}^{m_{j}} x_{a i j}{ }^{2}$ and $J_{b}=\frac{1}{r} \sum_{j}^{r} \sum_{i}^{m_{j}} x_{b i j}{ }^{2}$, where $J_{\mathrm{ab}}$ is the average identity of subpopulations $a$ and $b$, calculated as $J_{a b}=\frac{1}{r} \sum_{j}^{r} \sum_{i}^{m_{j}} x_{a i j} x_{b i j}$. Here, $x_{a i j}$ and $x_{b i j}$ are the frequencies of the $i$ th allele at the $j$ th locus in subpopulation $a$ and $b$, respectively. $D_{m}$ was calculated with a self-written code in R (Anonymous 2004). To account for the unbalanced sampling design, we used an averaged value of $D_{m}$ based on 1000 reduced data sets (see above). Principal coordinate analysis (PCoA) of genetic distance $D_{m}$ was calculated for a two-dimensional ordination space with the library stats (function cmdscale; R Development Core Team 2004) in R in order to assess if there were major differences in genetic distance among disturbance categories.

To test if there was spatial genetic structure in L. pulmonaria within the study area and if the structure differed between disturbance categories, we calculated three different types of variograms for each level of disturbance using the methods described in Wagner et al. (2005): (1) a variogram of gene diversity $H$ without accounting for recurrent genotypes, representing the overall spatial genetic structure, (2) a variogram of genotype diversity $D$, the probability of sampling a different multilocus genotype (Wagner et al. 2005), reflecting the clonal component, and (3) a variogram of $H$ weighted for recurrent genotypes, reflecting the sexual component. The weighting procedure is described in detail in Wagner et al. (2005). A lag distance of $50 \mathrm{~m}$ was chosen, with the first distance class containing only pairs of samples from the same tree and the last distance class containing all pairs of samples separated by more than $450 \mathrm{~m}$. Statistical significance of spatial autocorrelation was assessed for each variogram and each distance class using a one-sided permutation test with 100 permutations (Wagner et al. 2005). Exponential variogram models were fitted with the library gstat in R (Pebesma 2004).

\section{Results}

Non-spatial analysis

Deme census sizes of Lobaria pulmonaria in terms of the mean number of thalli were highest in the burnt area, followed by the logged area (Table 1). The mean cumulative thallus area per plot was largest in the burnt area (Table 1).

The minimum number of immigration events $C$ per deme ranged from one to eight. There was no statistically significant association between $C$ and disturbance $\left(\chi_{14}^{2}=16.6, P>0.05\right)$.

Among the 895 L. pulmonaria samples analysed, we found 176 multilocus genotypes $(M=$ $19.7 \%)$. Levene's tests of homoscedasticity showed that variances were homogeneous among treatment groups for $H(\mathrm{df}=2, F=1.94, P=0.157), G(\mathrm{df}=2, F=1.32, P=0.280)$, and $M(\mathrm{df}=2, F=2.22$, $P=0.123$ ). There was no statistically significant interaction between disturbance category and the 
number of colonised trees per plot in the analyses of covariance on $M$ and $H$; thus, the statistical models without interaction terms are shown (Table 2). There was a significant effect of disturbance on $H(P=0.012$; Table 2$)$ and on $M(P=0.005$; Table 2$)$, which were highest in logged demes, intermediate in uneven-aged demes, and lowest in burnt demes (Fig. 2). Gene diversity $H$ increased significantly with the number of colonised trees per plot, whereas the proportion of multilocus genotypes $M$ decreased (Fig. 3). In burnt demes, the number of multilocus genotypes $G$ did not increase significantly with the number of trees colonised by L. pulmonaria (Fig. 3a).

Demes belonging to the same disturbance category did not represent distinctive clusters with a noteworthy difference in genetic distance to other disturbance categories (Fig. 4). The logged demes represented a small cluster, and were generally more similar to each other than demes of the other two categories. Contrary, Logged and burnt demes showed a larger variance in genetic distance (Fig. 4).

\section{Spatial analysis}

At short distances, significant spatial autocorrelation in genotype diversity $D$ was detected in all disturbance categories (Fig. 5). Spatial autocorrelation of genotype diversity was significant at distances up to $50 \mathrm{~m}$ in logged demes, up to $100 \mathrm{~m}$ in uneven-aged demes, and up to $150 \mathrm{~m}$ in burnt demes. Genotype diversity was substantially reduced in burnt demes which showed the strongest spatial autocorrelation (Fig. 5).

Without accounting for recurrent multilocus genotypes, significant spatial autocorrelation in gene diversity $H$ extended up to $100 \mathrm{~m}$ in burnt demes, up to $50 \mathrm{~m}$ in uneven-aged demes, and up to 0 $\mathrm{m}$ (i.e., within trees) in logged demes (Fig. 6a). As in the variogram of $D$, the variogram of $H$ of burnt demes showed stronger spatial autocorrelation than the other disturbance categories (Fig. 6a).

When the effect of recurrent multilocus genotypes was accounted for (Fig. 6b), a low degree of spatial autocorrelation was only found in burnt demes in the first two distance classes and in the first distance class in logged demes. Most notably in Fig. 6, the value for the first distance class changed from $\sim 0.1$ to $\sim 0.4$ when recurrent genotypes were accounted for, indicating that much of the spatial autocorrelation was due to the clonal component. Note that due to the weighting of recurrent multilocus genotypes, the effective number of pairs per distance class was reduced from a range of formerly 1000 to 4000 pairs to 10 to 40 effective pairs. Therefore, the power of the significance test was low, and nonsignificance has to be interpreted carefully.

\section{Discussion}

The main objectives of this study were to determine if demes affected by stand-replacing disturbance (burnt) were founded by multiple immigration events, to assess spatial genetic structure, to evaluate dispersal ranges for the clonal and sexual component of genetic variation, and to test the effect of stand-level disturbances on genetic diversity of L. pulmonaria.

\section{Minimum number of immigration events}


We found no significant differences when we compared the minimum number of immigration events in demes among disturbance categories. Burnt and logged demes of L. pulmonaria were founded by independent immigration events from multiple sources, followed by rapid clonal spread at the deme level.

\section{Spatial genetic structure and dispersal ranges}

The clonal component had the largest impact on spatial genetic structure, as little spatial autocorrelation remained when clones were accounted for, implying that spatial autocorrelation owing to the sexual component of genetic variation was small by comparison. The variogram curve of genotype diversity of the burnt area was flatter, with significant spatial autocorrelation extending to a larger distance than those of the two other categories. Hence, the clonal component had a larger spatial extent in the burnt demes, suggesting substantial clonal spread. For instance, the more extensive clonal growth may have resulted from the lower original density of the lichen following fire and subsequent recolonisation by relatively few genotypes. Variogram analysis of gene diversity $H$ and of genotype diversity $D$ nevertheless showed that spatial autocorrelation due to clonal dispersal or selfing was confined to short distances. This implies that within the time since the stand-replacing disturbance in burnt demes (130 years), the majority of propagules resulting from vegetative propagation or selfing established within 150 meters' distance from their origin. The variogram analysis showed clearly that the range of clonal propagules was lower than that of ascospores (Fig. 6). As clonal propagules were abundant in the study area - almost every thallus we found exceeding $10 \mathrm{~cm}$ in diameter contained soredia (Scheidegger \& Goward 2002) - they may be important for the rapid colonisation of trees within forest stands at short distances. In contrast, the less abundant ascospores may serve as dispersal agents over longer distances, e.g. for the colonisation of distant forest patches. This hypothesis is supported by the lack of substantial spatial autocorrelation when recurrent genotypes were accounted for in the variogram of gene diversity. Hence, due to their size, ascospores seem to be more suitable for long-distance dispersal than vegetative propagules like thallus fragments, isidia or soredia (Bailey 1976; Galloway \& Aptroot 1995).

\section{Effect of disturbances on genetic diversity}

Old forests support more rare and endangered lichen species than younger forests (Lesica et al. 1991; Rose 1992; Dettki \& Esseen 1998; Boudreault et al. 2000), and old-forest associated lichens are commonly assumed to be negatively affected by logging mainly because of the loss of suitable habitat, e.g. old trees (Peterson \& McCune 2001; Hedenås \& Ericson 2003). However, in this study, we found evidence for the contrary: gene diversity and percentage of multilocus genotypes of the epiphytic old-forest lichen Lobaria pulmonaria was especially high in demes affected by stand-level timber logging as compared with tree-level logging. Moderate logging of trees, as in the uneven-aged forestry performed throughout the study area, may not reduce lichen populations significantly (Storaunet et al. 2000; Rolstad et al. 2001), thus still allowing for a high genetic diversity.

The main carrier tree of L. pulmonaria in the study area, sycamore maple, profits from temporally enhanced light conditions (Vittoz 1998). Stand-level logging in the western part of the study area may have led to a significant increase in sycamore maple density (Kalwij et al. in press). Taking this into consideration, the pattern observed in genetic diversity may be explained by an increase of 
available habitat. The genetic diversity of demes seems to reflect whether a subpopulation was reduced in size, i.e. to a high degree in the burnt area or a low degree in the other areas. Consecutively, genetic diversity accumulated over time in all areas as new immigrants arrived, but from different starting levels. The tree species which were selectively logged were possibly Picea abies, which does not provide suitable habitat of L. pulmonaria in the study area, and Fagus sylvatica, a tree species which is of secondary importance as carrier tree of L. pulmonaria in the study area (Kalwij et al. in press). Intensive selective logging of these tree species may have effects similar to tree harvesting with retention of the majority of trees containing L. pulmonaria. A recent modelling study indicates that the latter scenario is plausible (Wagner et al. submitted). Selective logging of $P$. abies and F. sylvatica might be beneficial for L. pulmonaria, but probably much less so for lichens dependent on the latter tree species as a carrier tree. Another point is that dense, dark forests are unfavourable for $L$. pulmonaria (Renhorn et al. 1997; Hazell \& Gustafsson 1999) and, thus, increased light availability may favour L. pulmonaria abundance in mixed forests as compared with stands dominated by P. abies.

The example of the burnt demes affected by stand-replacing disturbances about 130 years ago, which by now have reached large census sizes via multiple immigration events from different sources followed by rapid clonal spread within demes, and which have already reached a certain level of genetic diversity, showed that spatial distribution and the forming of genetic diversity in L. pulmonaria are not necessarily impacted by stand-replacing disturbances for many centuries. The reason for this might be the large local propagule pool in the study area. In contrast, in areas where the propagule pool of L. pulmonaria is small or where the clearing size or the distance to the closest population of potential founders is large, stand-replacing disturbances may influence the spatial occurrence and genetic diversity of L. pulmonaria for very long time periods. This is the case in large areas of Central Europe, where the species is largely restricted to autochthonous forests and where stand-replacing disturbances including clear-cutting have led to local extinction and a lack of recolonisation of secondary stands (Schöller 1997).

In the light of short, human time scales, L. pulmonaria may seem dispersal-limited, but relative to the length of its generation time of 35 years or more (Scheidegger \& Goward 2002), it is not. Hence, forest dynamics need to be appropriate to the generation time and dispersal ability of $L$. pulmonaria to ensure its persistence in a particular forest stand, comprising sufficient numbers of suitable carrier trees. This seems the case in the mixed forests of our study area, and may apply also in mixed or deciduous old-growth forests in other areas. In our study area, L. pulmonaria may indicate the occurrence of disturbance at suitable scales rather than ecological continuity of forests (Kalwij et al. in press), which is in accordance with the findings of Snäll et al. (2005), but is contrary to what most other studies have suggested (Andersson \& Appelqvist 1987; Rose 1992; Gauslaa 1994; Trass et al. 1999). In other landscapes, L. pulmonaria may still be considered an indicator of the presence of oldgrowth forests at the whole landscape level, but not necessarily locally, at the level of a particular local forest stand.

\section{Implications for conservation}

Our study suggests that retaining remnant trees carrying lichens should be an effective conservation strategy for rare epiphytic lichen species, which has also been suggested by Sillett et al. (2000) and Peterson \& McCune (2001). Care has to be taken that the forest clearings created by the 
logging process are kept small to keep a sufficiently moist microclimate in the stands and that, at the same time, gaps for colonisation of future carrier trees are created (Hedenås \& Ericson 2003). Selective cutting could then lead to an increased density of potential carrier tree species. Whether this hypothesised scenario does indeed take place is a question of the successional dynamics of the forest system and the lichen species under consideration. Lichens of primeval forests may well show different types of population dynamics.

\section{References}

Agresti A (1984) Analysis of ordinal categorical data. Wiley, New York.

Andersson L, Appelqvist T (1987) Lunglav och almlav, indikatorer på värdefull lövskog. Svensk Botanisk Tidsskrift 91, 185-194.

Anonymous (2004) R Version 2.0.0 for Windows. http://cran.r-project.org.

Aptroot A, van Herk CM, Sparrius LB, van den Boom PPG (1999) Checklist van de Nederlandse Korstmossen en Lichenicole Fungi. Buxbaumiella 50, 4-64.

Bacles CFE, Burczyk J, Lowe AJ, Ennos RA (2005) Historical and contemporary mating patterns in remnant populations of the forest tree Fraxinus excelsior L. Evolution 59, 979-990.

Bailey RH (1976) Ecological aspects of dispersal and establishment in lichens. In: Lichenology: progress and problems (eds. Brown DH, Hawksworth DL, Bailey RH) pp. 215-247. Academic Press, London.

Baucom RS, Estill JC, Cruzan MB (2005) The effect of deforestation on the genetic diversity and structure in Acer saccharum (Marsh): evidence for the loss and restructuring of genetic variation in a natural system. Conservation Genetics 6, 39-50.

Boudreault C, Gauthier S, Bergeron Y (2000) Epiphytic lichens and bryophytes on Populus tremuloides along a chronosequence in the southwestern boreal forest of Québec, Canada. The Bryologist 103, 725-738.

Bradshaw RHW (2004) Past anthropogenic influence on European forests and some possible genetic consequences. Forest Ecology and Management 197, 203-212.

Dettki H, Esseen PA (1998) Epiphytic macrolichens in managed and natural forest landscapes: a comparison at two spatial scales. Ecography 21, 613-624.

Frankham R, Ballou JD, Briscoe DA (2002) Introduction to conservation genetics. Cambridge University Press, Cambridge.

Galloway DJ, Aptroot A (1995) Bipolar lichens: a review. Cryptogamic Botany 5, 184-191.

Gauslaa Y (1994) Lungenever, Lobaria pulmonaria, som indikator på artsrike kontinuitetsskoger. Blyttia 3, 119-128.

Gilbert OL (1977) Lichen conservation in Britain. In: Lichen ecology (ed. Seaward MRD) pp. 415-436. Academic Press, London.

Gillet F, Besson O, Gobat J-M (2002) PATUMOD: a compartment model of vegetation dynamics in wooded pastures. Ecological Modelling 147, 267-290.

Gonzalez-Astorga JG, Cruz-Angon A, Flores-Palacios A, Vovides AP (2004) Diversity and genetic structure of the Mexican endemic epiphyte Tillandsia achyrostachys E. Morr. ex Baker var. achyrostachys (Bromeliaceae). Annals of Botany 94, 545-551.

Hallingbäck T, Martinsson PO (1987) The retreat of two lichens, Lobaria pulmonaria and L. scrobiculata in the district of Gäsene (SW Sweden). Windahlia 17, 27-32.

Hartl DL, Clark AG (1997) Principles of population genetics. Sinauer, Sunderland. 
Hazell P, Gustafsson L (1999) Retention of trees at final harvest - evaluation of a conservation technique using epiphytic bryophyte and lichen transplants. Biological Conservation 90, 133142.

Hedenås H, Ericson L (2003) Response of epiphytic lichens on Populus tremula in a selective cutting experiment. Ecological Applications 13, 1124-1134.

Högberg N, Kroken S, Thor G, Taylor JW (2002) Reproductive mode and genetic variation suggest a North American origin of European Letharia vulpina. Molecular Ecology 11, 1191-1196.

Kalwij JM, Wagner HH, Scheidegger C (in press) Effects of stand-replacing disturbance events on the spatial distribution of a lichen indicator of forest conservation value. Ecological Applications.

Kirby KJ, Thomas RC, Key RS, McLean IFG, Hodgetts N (1995) Pasture-woodland and its conservation in Britain. Biological Journal of the Linnean Society 56, 135-153.

Lesica P, McCune B, Cooper SV, Hong WS (1991) Differences in lichen and bryophyte communities between old-growth and managed second-growth forests in the Swan Valley, Montana. Canadian Journal of Botany 69, 1745-1755.

Mantel N (1967) The detection of disease clustering and a generalized regression approach. Cancer Research 27, 209-220.

Myllys L, Stenroos S, Thell A, Ahti T (2003) Phylogeny of bipolar Cladonia arbuscula and Cladonia mitis (Lecanorales, Euascomycetes). Molecular Phylogenetics and Evolution 27, 58-69.

Nason JD, Hamrick JL (1997) Reproductive and genetic consequences of forest fragmentation: Two case studies of neotropical canopy trees. Journal of Heredity 88, 264-276.

Nei M (1978) Estimation of average heterozygosity and genetic distance from a small number of individuals. Genetics 89, 583-590.

Nei M, Maruyama T, Charkaborty R (1975) The bottleneck effect and genetic variability in populations. Evolution 29, 1-10.

Pebesma EJ (2004) gstat: Uni- and multivariable geostatistical modelling, prediction and simulation. URL http://www.gstat.org/.

Peterson EB, McCune B (2001) Diversity and succession of epiphytic macrolichen communities in low-elevation managed conifer forests in Western Oregon. Journal of Vegetation Science 12, 511-524.

30 Pither R, Shore JS, Kellman M (2003) Genetic diversity of the tropical tree Terminalia amazonia (Combretaceae) in naturally fragmented populations. Heredity 91, 307-313.

Printzen C, Ekman S (2003) Local population subdivision in the lichen Cladonia subcervicornis as revealed by mitochondrial cytochrome oxidase subunit 1 intron sequences. Mycologia 95, 399406.

Printzen C, Ekman S, Tønsberg T (2003) Phylogeography of Cavernularia hultenii: evidence of slow genetic drift in a widely disjunct lichen. Molecular Ecology 12, 1473-1486.

R Development Core Team (2004) R: a language and environment for statistical computing. URL http://www.R-project.org.

Renhorn KE, Esseen PA, Palmqvist K, Sundberg B (1997) Growth and vitality of epiphytic lichens. I. Responses to microclimate along a forest edge-interior gradient. Oecologia 109, 1-9.

Rolstad J, Gjerde I, Storaunet KO, Rolstad E (2001) Epiphytic lichens in Norwegian coastal spruce forest: historic logging and present forest structure. Ecological Applications 11, 421-436.

Rose F (1992) Temperate forest management: its effects on bryophyte and lichen floras and habitats. In: Bryophytes and lichens in a changing environment (eds. Bates JW, Farmer AM) pp. 211233. Clarendon Press, Oxford. 
Scheidegger C, Clerc P, Dietrich M, Frei M, Groner U, Keller C, Roth I, Stofer S, Vust M (2002) Rote Liste der gefährdeten Arten der Schweiz: Baum- und erdbewohnende Flechten. BUWAL, Bern.

Scheidegger C, Frey B, Zoller S (1995) Transplantation of symbiotic propagules and thallus fragments: methods for the conservation of threatened epiphytic lichen populations. Mitteilungen der Eidgenössischen Forschungsanstalt für Wald Schnee und Landschaft 70, 41-62.

Scheidegger C, Goward T (2002) Monitoring lichens for conservation: Red Lists and conservation action plans. In: Monitoring with lichens - monitoring lichens (eds. Nimis PL, Scheidegger C, Wolseley PA) pp. 163-181. Kluwer Academic Publishers, Dordrecht.

Scheidegger C, Walser JC (1998) Reintroduction and augmentation of populations of the endangered Lobaria pulmonaria: methods and concepts. In: Lobarion lichens as indicators of the primeval forests of the eastern Carpathians (eds. Kondratyuk S, Coppins B) pp. 33-52. Kostrino, Ukraine.

Schöller H (1997) Flechten - Geschichte, Biologie, Systematik, Ökologie, Naturschutz und kulturelle Bedeutung. Senkenbergische Naturforschende Gesellschaft, Frankfurt a. M.

Seaward MRD (1982) Principles and priorities of lichen conservation. Journal of Hattori Botanical Laboratory 52, 401-406.

Sillett SC, McCune B, Peck JE, Rambo TR, Ruchty A (2000) Dispersal limitations of epiphytic lichens result in species dependent on old-growth forests. Ecological Applications 10, 789 - 799.

Snäll T, Ehrlen J, Rydin H (2005) Colonization-extinction dynamics of an epiphyte metapopulation in a dynamic landscape. Ecology 86, 106-115.

Søchting U, Alstrup V (2002) Danish lichen checklist. Version 1. URL http://www.bi.ku.dk/lichens/dkchecklist/.

Sork VL, Smouse PE, Apsit VJ, Dyer RJ, Westfall RD (2005) A two-generation analysis of pollen pool genetic structure in flowering dogwood, Cornus florida (Cornaceae), in the Missouri Ozarks. American Journal of Botany 92, 262-271.

Storaunet KO, Rolstad J, Groven R (2000) Reconstructing 100 - 150 years of logging history in coastal spruce forest (Picea abies) with special conservation values in central Norway. Scandinavian Journal of Forest Research 15, 591-604.

Takezaki N, Nei M (1996) Genetic distances and reconstruction of phylogenetic trees from microsatellite DNA. Genetics 144, 389-399.

Tanaka Y (2000) Extinction of populations by inbreeding depression under stochastic environments. Population Ecology 42, 55-62.

Taylor JW, Jacobson DJ, Kroken S, Kasuga T, Geiser DM, Hibbett DS, Fisher MC (2000) Phylogenetic species recognition and species concepts in fungi. Fungal Genetics and Biology 31, 21-32.

Trapnell DW, Hamrick JL (2005) Mating patterns and gene flow in the neotropical epiphytic orchid, Laelia rubescens. Molecular Ecology 14, 75-84.

Trass H, Vellak K, Ingerpuu N (1999) Floristical and ecological properties for identifying of primeval forests in Estonia. Annales Botanici Fennici 36, 67-80.

40 Türk R, Hafellner J (1999) Rote Liste gefährdeter Flechten (Lichenes) Österreichs. In: Rote Listen gefährdeter Pflanzen Österreichs, 10 (ed. Niklfeld H) pp. 187-228. Austria Medien Service, Graz.

Vekemans X, Schierup MH, Christiansen FB (1998) Mate availability and fecundity selection in multiallelic self-incompatibility systems in plants. Evolution 52, 19-29. 
Vittoz P (1998) Flore et végétation du Parc jurassien vaudois: typologie, écologie et dynamique des milieux. PhD thesis, University of Lausanne, Lausanne.

Volis S, Bohrer G, Oostermeijer G, Van Tienderen P (2005) Regional consequences of local population demography and genetics in relation to habitat management in Gentiana pneumonanthe. Conservation Biology 19, 357-367.

Wagner HH, Holderegger R, Werth S, Gugerli F, Hoebee SE, Scheidegger C (2005) Variogram analysis of the spatial genetic structure of continuous populations using multilocus microsatellite data. Genetics 169, 1739-1752.

Wagner HH, Werth S, Kalwij JM, Scheidegger C (submitted) Landscape genetic modeling of forest recolonization by an epiphytic lichen. Landscape Ecology.

Walser JC, Gugerli F, Holderegger R, Kuonen D, Scheidegger C (2004) Recombination and clonal propagation in different populations of the lichen Lobaria pulmonaria. Heredity 93, 322-329.

Walser JC, Holderegger R, Gugerli F, Hoebee SE, Scheidegger C (2005) Microsatellites reveal regional population differentiation and isolation in Lobaria pulmonaria, an epiphytic lichen. Molecular Ecology 14, 457-467.

Walser JC, Sperisen C, Soliva M, Scheidegger C (2003) Fungus-specific microsatellite of lichens: application for the assessment of genetic variation on different spatial scales in Lobaria pulmonaria. Fungal Genetics and Biology 40, 72-82.

Walser JC, Zoller S, Büchler U, Scheidegger C (2001) Species-specific detection of Lobaria pulmonaria (lichenized ascomycete) diaspores in litter samples trapped in snow cover. Molecular Ecology 10, 2129-2138.

Widmer A, Lexer C (2001) Glacial refugia: sanctuaries for allelic richness, but not for gene diversity. Trends in Ecology and Evolution 16, 267-269.

Wirth V (1995) Die Flechten Baden-Württembergs. Eugen Ulmer, Stuttgart.

Wirth V, Schöller H, Scholz P, Ernst G, Feuerer T, Gnüchtel A, Hauck M, Jacobsen P, John V, Litterski B (1996) Rote Liste der Flechten (Lichenes) der Bundesrepublik Deutschland. Schriftenreihe für Vegetationskunde 28, 307-368.

Yoshimura I (1971) The genus Lobaria of Eastern Asia. Journal of the Hattori Botanical Laboratory 34, 231-364.

30 Zoller S, Lutzoni F, Scheidegger C (1999) Genetic variation within and among populations of the threatened lichen Lobaria pulmonaria in Switzerland and implications for its conservation. Molecular Ecology 8, 2049-2059.

\section{Acknowledgements}

We thank Carolina Cornejo, Christoph Sperisen, and Jean-Claude Walser for fruitful discussions on lab methods, and Daniela Csencsics and Johanna Scheidegger for field assistance. This research is part of a project funded by the Swiss National Science Foundation (SNF) under the NCCR Plant Survival.

\section{Figure Legends}

40 Figure 1. Demes of Lobaria pulmonaria in the Swiss study area subjected to molecular-genetic analyses, and reconstructed stand-level disturbances (Kalwij et al. in press). Each circle, square and triangle represents the central coordinates of a deme. The disturbance category of demes is shown by 
squares (burnt), circles (uneven-aged), and triangles (logged). The upper left panel indicates the location of the study area within Switzerland, as indicated by the arrow.

Figure 2. Relationship between disturbance category and number of multilocus genotypes per deme $(G)$, percentage of multilocus genotypes per deme $(M)$, and unbiased gene diversity $(H)$ for Lobaria pulmonaria demes from the Swiss Jura. Figures (a) to (c) show means and $95 \%$ confidence intervals.

Figure 3. Relationship between number of multilocus genotypes per deme $(G)$, percentage of multilocus genotypes per deme $(M)$, unbiased gene diversity $(H)$, disturbance category and logtransformed number of colonised trees for Lobaria pulmonaria demes from the Swiss Jura. Figures (a) to (c), analysis of covariance of the effect of disturbance categories on $G, M$ and $H$. East symbol represents a deme. Squares, broken line: burnt; circles, black line: uneven-aged; triangles, dotted line: logged.

Figure 4. Ordination of the first two axes of Principal Coordinate Analysis (PCoA) of demes using Nei's minimum genetic distance $\left(D_{m}\right)$ in Lobaria pulmonaria. Each symbol represents a deme, and minimum convex polygons were drawn for each disturbance category to show potential overlap. The variance explained by the first two PCoA-axes was $43.0 \%$. Squares, broken line: burnt; circles, black line: uneven-aged; triangles, dotted line: logged.

Figure 5. Variogram of genotype diversity $(D)$ in Lobaria pulmonaria from the Swiss study area. Each symbol indicates the probability of sampling two different multilocus genotypes as a function of their distance in space. Squares, broken line: burnt; circles, black line: uneven-aged; triangles, dotted line: logged. Filled symbols indicate significant spatial autocorrelation.

Figure 6. Variogram of gene diversity $(H)$ in Lobaria pulmonaria from the Swiss study area. Each symbol indicates the probability of sampling two different alleles of a locus, averaged over six loci, as a function of their distance in space. (a) Not accounting for recurrent genotypes; (b) accounting for recurrent genotypes. Squares, broken line: burnt; circles, black line: uneven-aged; triangles, dotted line: logged. Filled symbols indicate significant spatial autocorrelation. 
Table 1. The number of sampling plots investigated (number of demes), average deme census size (number of thalli), and thallus area (area) of Lobaria pulmonaria in 1-ha plots from the Swiss Jura Mountains, in relationship to disturbance. Four plots had missing data, and were thus not shown.

\begin{tabular}{lccc}
\hline Disturbance category of deme & Area $\left[\mathrm{dm}^{2}\right]$ & $\begin{array}{l}\text { Number of } \\
\text { thalli }\end{array}$ & $\begin{array}{l}\text { Number of } \\
\text { demes }\end{array}$ \\
\hline Burnt & 572.9 & 930 & 11 \\
Logged & 405.6 & 810 & 9 \\
Uneven-aged & 413.8 & 717 & 17 \\
\hline
\end{tabular}


Table 2. Analyses of covariance testing the effect of disturbance (factor) and of the log-transformed number of Lobaria pulmonaria trees per deme (number of trees $=$ covariate) on the number of multilocus genotypes $(G)$ per deme, the percentage of multilocus genotypes $(M)$ in demes and Nei's unbiased gene diversity $(H)$ in the Swiss study area. $\mathrm{SS}=$ sum of squrares, $\mathrm{df}=$ degrees of freedom, $F$ = F-ratio. Note that the response variable $H$ was square-root transformed prior to analysis, while all other response variables remained untransformed.

\begin{tabular}{llrrrr}
\hline $\begin{array}{l}\text { Diversity } \\
\text { parameter }\end{array}$ & Source of variation & SS & df & \multicolumn{1}{c}{$F$} & $P$ \\
\hline$G$ & Number of trees & 220.0 & 1 & 49.72 & $<0.0001$ \\
& Disturbance & 24.6 & 2 & 2.78 & 0.0759 \\
& Number of trees $\times$ Disturbance & 36.1 & 2 & 4.08 & 0.0255 \\
& Error & 154.9 & 35 & & \\
& Total & 435.6 & 40 & & \\
& Number of trees & & & & \\
& Disturbance & 0.646 & 1 & 12.72 & 0.0010 \\
& Error & 0.621 & 2 & 6.11 & 0.0051 \\
& Total & 1.879 & 37 & & \\
& Number of trees & 3.145 & 40 & & \\
& Disturbance & & & & \\
& Error & 0.601 & 1 & 8.05 & 0.0073 \\
& Total & 0.743 & 2 & 4.98 & 0.0121 \\
& & 2.763 & 37 & & \\
\hline
\end{tabular}




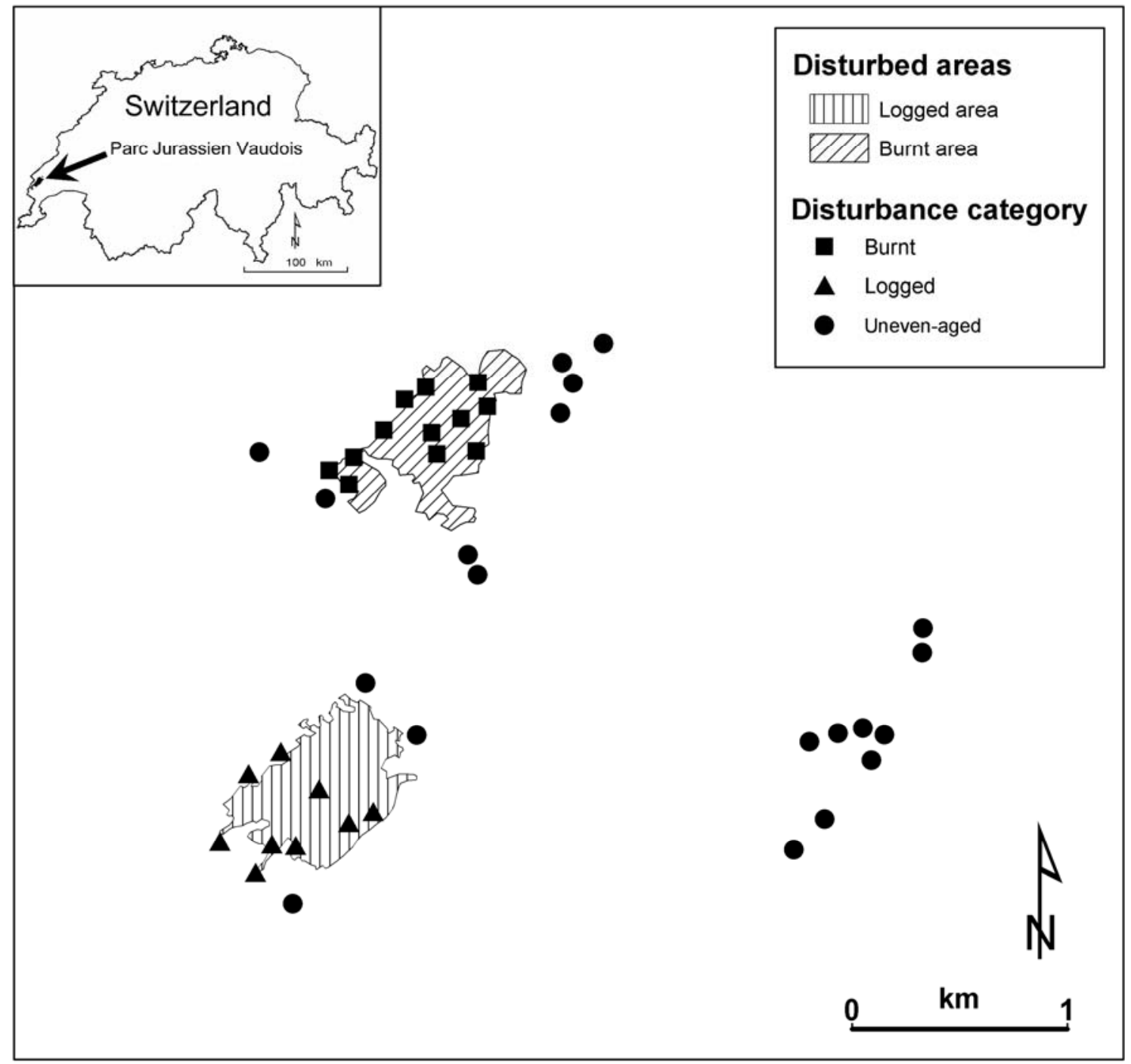

Figure 1 

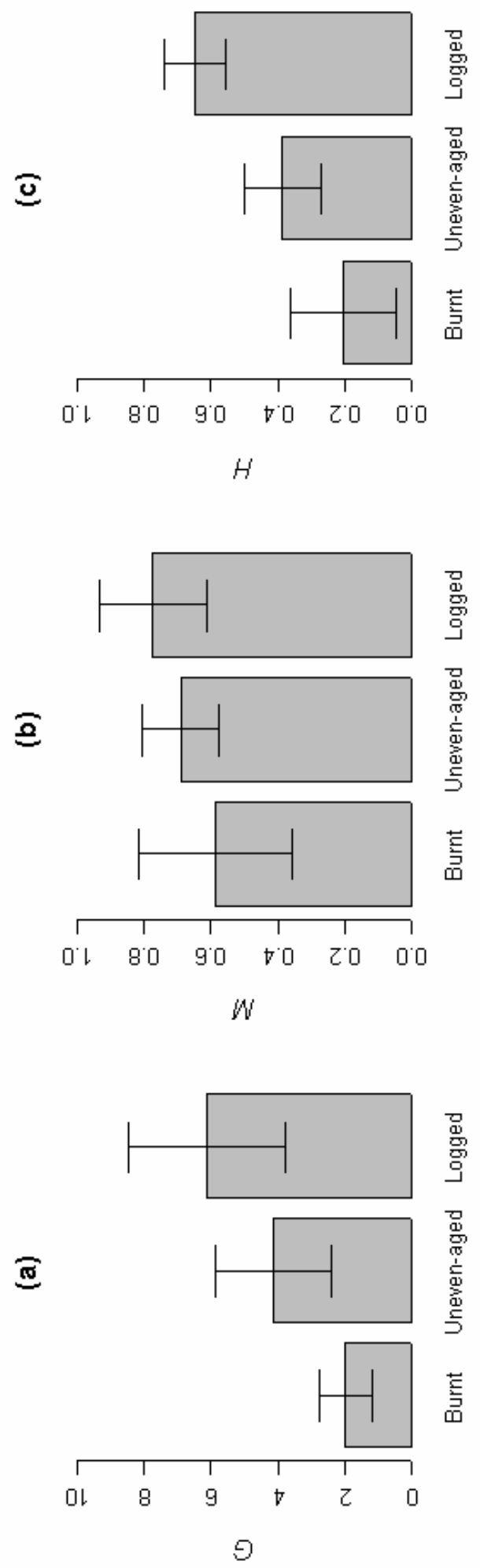

Figure 2 


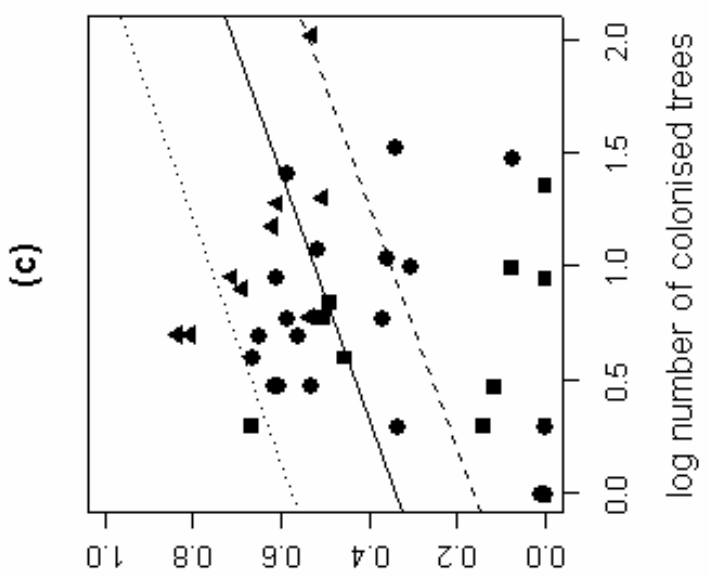

$H$

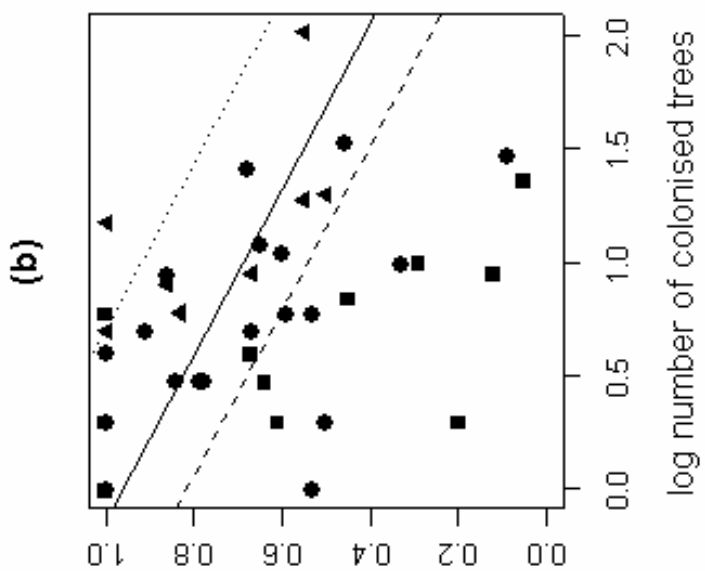

W

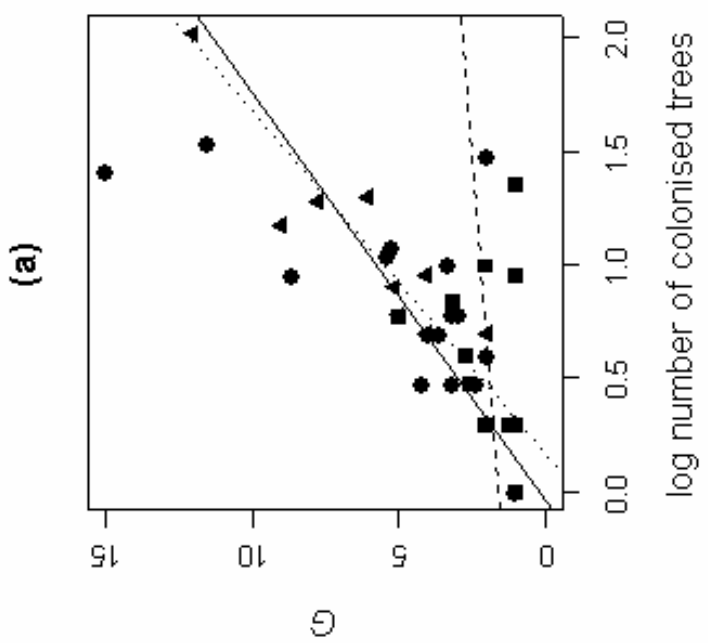

Figure 3 
Genetic diversity is affected by disturbances

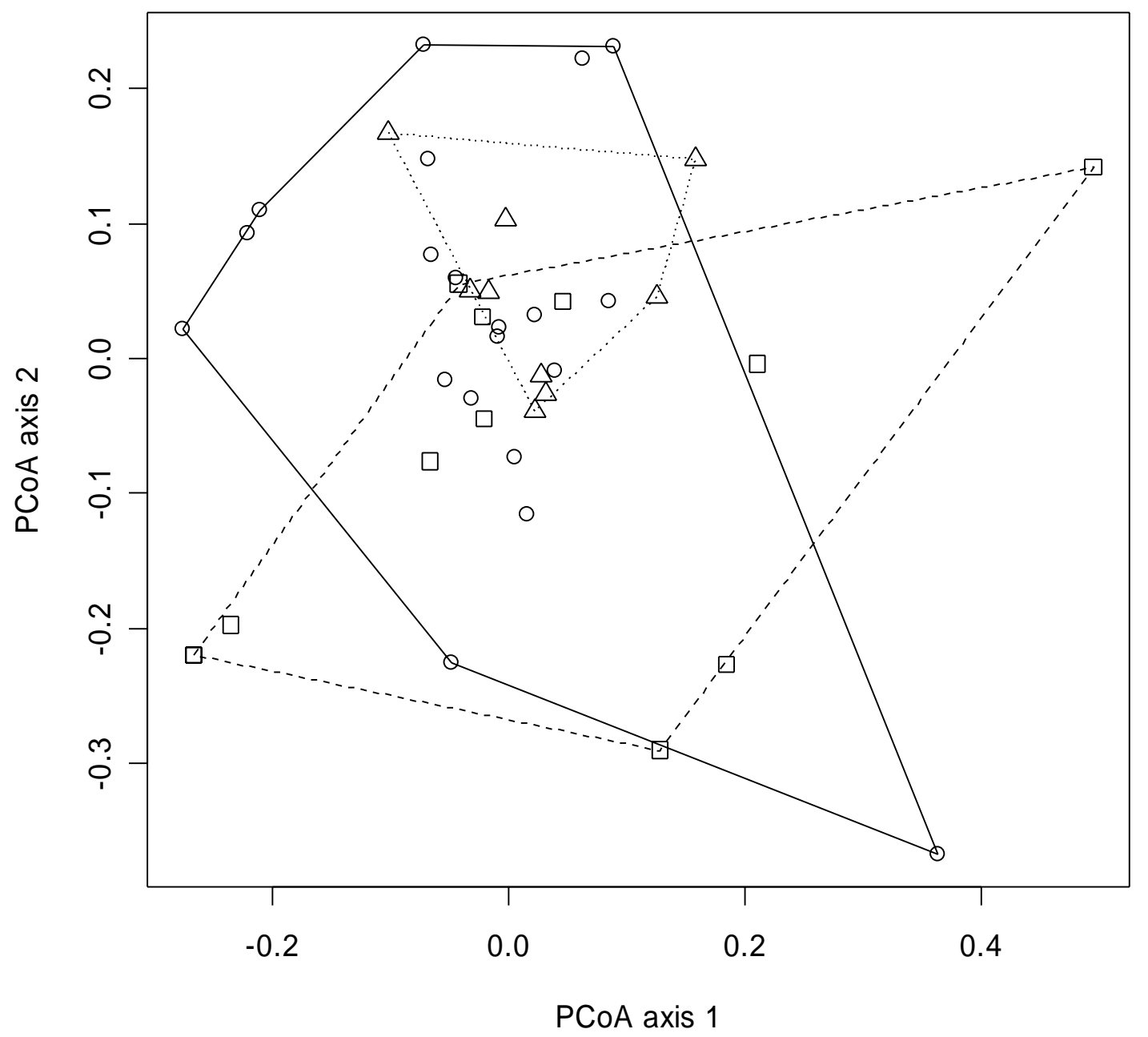

Figure 4 
Genetic diversity is affected by disturbances

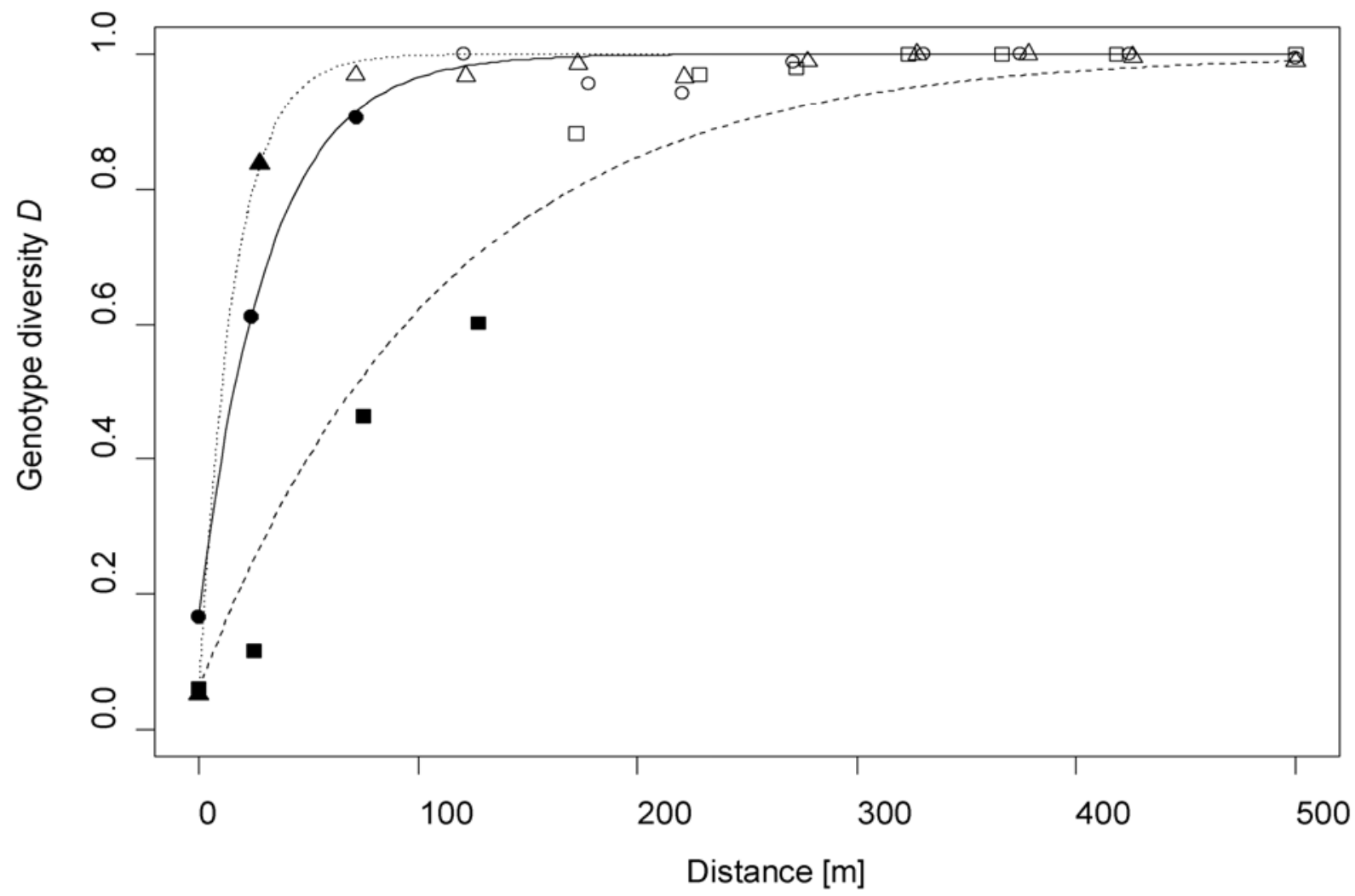

Figure 5 
Genetic diversity is affected by disturbances
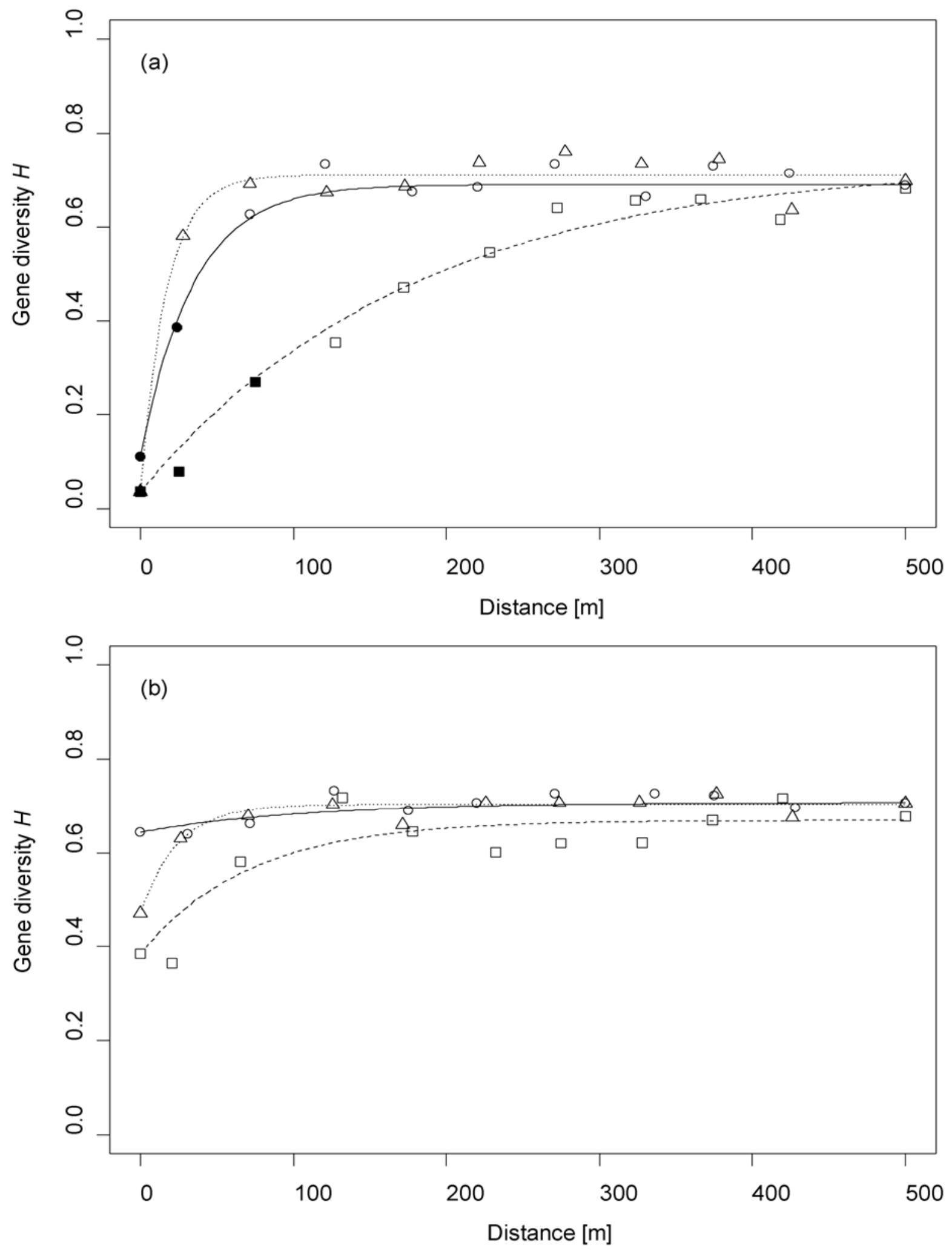

Figure 6 


\section{Author information box}

This work is part of Silke Werth's dissertation research on landscape genetics and dispersal of lichenised fungi. She will continue studying landscape genetics of lichenised fungi at the University of California at Los Angeles. Helene H. Wagner focuses on spatial analysis and modelling as applied in community ecology and landscape genetics. Rolf Holderegger investigates the population and landscape genetics of plants and their application in conservation biology. Jesse M. Kalwij's PhD focused on reconstructing stand-replacing disturbances based on aerial images and on ecological indicators of conservation value. He is currently doing research on the ecology of invasive species at the Centre of Excellence for Invasion Biology (CIB), University of Stellenbosch. Christoph

10 Scheidegger is head of the Division Ecological Genetics at the WSL Swiss Federal Research Institute, and his research interests cover ecophysiology, population genetics, morphology, and conservation biology of lichenised fungi. 